$14^{\text {th }}$ Conf. Agric. Develop. Res., Fac. of Agric., Ain Shams Univ., March, 2019, Cairo, Egypt

Special Issue, 27(1), 649 - 657, 2019

Website: http://strategy-plan.asu.edu.eg/AUJASCI/

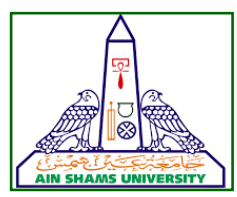

649

\title{
LIPID METABOLISM IN DIABETIC RATS AS AFFECTED BY CANOLA AND MUSTARD SEED SPROUTS
}

$[60]$

\author{
Hanaa M. Amer ${ }^{1 \star}$, Tahany, A.A. Aly ${ }^{2}$, Tobgy, K.M. ${ }^{1}$, Abdallah $^{3}$, M.M.F. \\ and El-Shahat, $\mathrm{N}^{4}$
}

1. Horticulture Research Institute, Agricultural Research Center (ARC), Giza, Egypt.

2. Regional Center for Food and Feed, ARC, Giza- Egypt .

3. Horticulture Dept., Fac. of Agric., Ain Shams Univ., P.O. Box 68, Hadyak Shoubra, 11241, Cairo, Egypt.

4. Agric. Biochemistry Dept., Fac. of Agric., Ain Shams Univ., P.O. Box 68, Hadyak Shoubra, 11241, Cairo, Egypt.

${ }^{*}$ Corresponding author: nonaamer637@gmail.com

Received 13 October, 2018, $\quad$ Accepted 30 October, 2018

\section{ABSTRACT}

Canola (Brassica juncea L.) and mustard (Sinapis alba L.) seed sprout effects on diabetic rats have no available information and to clarify their effects, both sprouts were investigated in streptozotocin (STZ) induced diabetic and normal rats. Rats were fed on a semi-modified diet containing $10 \%$ of canola or mustard sprouted using tap or saline water for sprouting ad-libitum for 6 weeks. STZ showed increases in blood sugar, low density lipoprotein cholesterol (LDL-c), vary low density lipoprotein cholesterol (VLDL-c) and triglycerides (TG). The addition of canola and mustard with or without salinty at $10 \%$ to diabetic rats diet as semimodified diet resulted a significant decrease in blood glucose, TG and VLDL-c and data was more pronounced using mustard sprouted or saline water without changes in the HDL-c parameter. These results showed that canola and mustard especially mustard sprouted in saline water had a hypoglycemic activity in diabetic rats and partly improved lipid metabolism in the experimental rats, with non-toxic to rats in doses given over 6 weeks period in this study.

Keywords: Lipid metabolism, Canola, Mustard, Sprouts, Streptozotocin, Diabetic

\section{INTRODUCTION}

When a person has high blood glucose, either because pancreas cells do not respond to the insulin that is produced, or because the pancreas does not produce enough insulin, or its a group of metabolic diseases called diabetes mellitus as define by Rani and Kumar (2014). A single dose of STZ of $60 \mathrm{mg} / \mathrm{kg}$ body weight. intraperitoneally into rats results in hyperglycaemia within 72 hours (George et al 2010 and Tahmasebpourl et al 2013).

Streptozotocin induces one type of diabetes which is similar to diabetes mellitus with nonketosis hyperglycemia in some animal species (Gajdosik et al 1999 and Akbarzadeh et al 2007).

The role of insulin in carbohydrate metabolism is to stimulate the disposal of ingested glucose into skeletal muscle and adipose tissue and to reduce hepatic glucose production by decreasing gluconeogenesis and glycogenolysis (Bessesen, 2001). Insulin suppresses the release of free fatty acids from adipose tissue by inhibiting lipolysis in lipid metabolism (Bessesen, 2001).

Al-Logmanli and Zari (2009) and Aly Tahany et al (2015) found that STZ- induced diabetic rats showed significant increases in the levels of blood sugar, cholesterol (TC), low density lipoprotein 
cholesterol (LDL-C) and triglycerides (TG), while body weight, was decreased compared to normal rats.

Beneficial effects on diabetes mellitus have been reported using natural products. For instance, because of the increase of insulin sensitivity caused by green tea antioxidant (polyphenol), green tea has been reported to decrease the plasma levels of blood glucose and insulin in rats (Wu et al 2004). Also vitamin $E$ was reported to improve insulin sensitivity in rats fed a high fructose diet (Faure et al 1997).

In the end of passed century, the attention of experts dealing with the healthy nutrition turned more and more towards the determination of the biological value of the nutritional sprouts (Penas et al 2008).

Dietary broccoli sprout at $10 \mathrm{~g}$ per day (4 weeks) improved insulin resistance among type II diabetic human patients also significantly improved blood lipid profile, decreased blood serum triglycerides and increased HDL-C concentration among human patients (Bahadoran et al 2012). White radish sprout improved plasma metabolites and lipid metabolism (Hashimoto et al 2006, Taniguchi et al 2006 and Aly Tahny et al 2015).

Chickpea sprouts improved lipid metabolism (Mao et al 2008). Five weeks dietary intake of mung bean sprout lowered blood glucose, cholesterol and triglyccride (Yao et al 2008). Wheat sprout is therapeutic for diabetes mellitus because wheat sprouts stimulate insulin secretion (Lee et al 2012).

All lipid parameters expect HDL-c significantly elevated in diabetic rat as compared to normal control rat as reported by Ravi et al (2005), AlLogmani and Zari (2009), Alnahdi et al (2012) and Ahmed et al (2014).

The present study investigated the influence of canola and mustard seed spurouts with and without salin water as semi-modified diet on blood sugar and lipid metabolites in normal and STZinduced diabetic rats.

\section{MATERIALS AND METHODS}

\section{Materials}

Seeds of canola and mustard cv.Balady were obtained from private seed market. Canola and mustard belong to Cruciferous family. The seeds were cleaned from all impurities for sprouting using jar method described by Abdallah (2008). The harvest sprouts ( 3 days old for canola and 6 days for mustard for both germinated in tap water "TWS" and in $1000 \mathrm{ppm} \mathrm{NaCl}$ solution "SWS"), were washed and sun-air dried for 3 day according to Dzowela et al (1995) before crushed into powder for rat diet. Streptozotocin (STZ) was obtained from Biomedicals.

\section{Experimental animals and diabetes}

This study has been done using 36 male Albino Spargue-Dawely rats with a mean weight of $158 \pm$ $18 \mathrm{~g}$. The rats were provided by the animal house of the Egyptian Organization of Biological Products and Vaccines, Egypt. They were raised in the animal house of Biology Laboratory, Faculty of Agricultural, Cairo University, Giza, Egypt. The animals were divided into six equal groups of 6 rats; each and housed individually in stainless steel cages with wire mesh bottoms and maintained at $25 \pm 2$ ${ }^{\circ} \mathrm{C}$, relative humidity of $50-60 \%$ and $12 / 12 \mathrm{~h}$ light/dark cycle throughout the experiment for a week for laboratory acclimatization. Five groups of the rats were injected intraperitoneally with STZ (60 mg / kg body weight) to induce a diabetic status according to George et al (2010), Tahmasebpourl et al (2013) and Aly Tahany et al (2015).

\section{The experimental design}

The six groups of rats were detalied as follows:

G1 = Normal health control rats fed on astandard diet.

$\mathrm{G} 2=$ Diabetic control rats fed on astandard diet.

G3 = Diabetic rats fed on SWS canola semimodified diet.

G4- Diabetic rats fed on TWS canola semimodified diet.

G5= Diabetic rats fed on SWS mustard semimodified diet.

G6- Diabetic rats fed on TWS mustard semimodified diet.

Standard (AIN-76 diet) prepared for G1 and G2 groups and fed on semi-modified diets (AIN-76 diet) containing $10 \%$ of SWS and TWS canola prepared for G3 and G4 respectively or $10 \%$ SWS and TWS mstard prepared for G5 and G6, respectively. at the expense of corn starch

ad libitum for 6 weeks. observing body weights. The composition of normal standard diets (AIN-76 diet) contained the following component: corn starch mix $65 \%$, casein $20 \%$, cellulose powder $5 \%$, corn oil $5 \%$, 
AIN-76 mineral mix 3.5\%, AIN-76 vitamin mix $1.0 \%$,methionine $0.3 \%$ and choline chloride $0.2 \%$. Blood sample collection and glucose determination

Six blood samples were collected from rats of each group from the retero oribital plexus of veins according to Shermer (1967) after six week in clean dry sterile and labeled centrifuge tubes.Rats were fasted for $12 \mathrm{~h}$, and then slightly anaesthetized with carbon dioxide gas. Separating serum was done by centrifugation at 1500 r.p.m for $5 \mathrm{~min}$. Blood sugar was determined enzymatic colorimetrically in the serum according to the method of Trinder (1969).

\section{Analytical Methods}

The total cholesterol (TC), low density lipoprotein cholesterol (LDL-c) and high density lipoprotein cholesterol (HDL-c) and serum levels triglycerides (TG) were measured with an automatic anolyzer using diognostic kit for eash according to Fossati et al (1982), Allain et al (1974), Wieland and Seidel (1983) and Burstein et al (1980) respectively. Very low-density lipoprotein cholesterol (VLDL-c) by subdivision (TG $\backslash 5$ ).

\section{Statistical analysis}

Obtained data were statistically analyzed according to the method of Snedecor and Cochran (1980) and LSD $(P<0.05)$ was used to compare the significant difference between mean of treatments.

\section{RESULTS AND DISCUSSION}

\section{1- Effect of sprouting using saline water on canola and mustard sprout characters}

Data in Table (1) showed fresh weight of canola and mustard sprout ratio about 1:6.9 and about 1:3.3 per equal fresh weight of canola and mustard seed, respectively which obtained by using jar method for 3 day old canola and 6 day old mustard sprout.

However canola ratio (> 1:5) was obtained before on clover sprouts by Sawyer et al (1985) and Abdallah (2008). While, mustard recorded lower sprout ratio. However, the sprout ratio increased with sprouting using allow $\mathrm{NaCl}$ concentration compared with using tap water for both canola $z$. mustard. The sprout average length was $4.02 \mathrm{~cm}$ for canola sprout and about $2.93 \mathrm{~cm}$ for mustard sprout using tap water for sprouting. Using $\mathrm{Na} \mathrm{Cl}$ at $1000 \mathrm{ppm}$ recorded the tallest canola sprout length $(5.38 \mathrm{~cm})$ while $2000 \mathrm{ppm}$ recorded the tallest mustard sprout length $(3.52 \mathrm{~cm})$. The increment in the sprout ratio and length regarded to the higher fresh weight of sprout, since the sprout had greater water content than the original on a fresh - weight basis.

Table 1. Effect of $\mathrm{NaCl}$ concentrations_in sprouting solution on 3 day old etiolated canola and 6 day mustard sprouts characters. (Combined of two experiments)

\begin{tabular}{|l|c|c|c|c|c|}
\hline $\begin{array}{l}\text { NaCl Character } \\
\text { Concentration }\end{array}$ & $\begin{array}{c}\text { Sprout radi- } \\
\text { cal length } \\
(\mathbf{c m})\end{array}$ & $\begin{array}{c}\text { Sprout hypocot- } \\
\text { yl length } \\
(\mathbf{c m})\end{array}$ & $\begin{array}{c}\text { Sprout } \\
\text { length } \\
(\mathbf{c m})\end{array}$ & $\begin{array}{c}10 \text { sprouts } \\
\text { fresh weight } \\
(\mathbf{m g})\end{array}$ & $\begin{array}{c}10 \text { sprouts } \\
\text { dry weight } \\
\text { (mg) }\end{array}$ \\
\hline & Canola & \multicolumn{4}{|c|}{3 day old } \\
\hline Control (Tap water) & $4.02 \mathrm{bc}$ & $2.083 \mathrm{a}$ & $1.864 \mathrm{a}$ & $0.210 \mathrm{a}$ & $0.041 \mathrm{a}$ \\
$1000 \mathrm{ppm}$ & $5.38 \mathrm{a}$ & $3.113 \mathrm{a}$ & $2.273 \mathrm{a}$ & $0.237 \mathrm{a}$ & $0.023 \mathrm{a}$ \\
$2000 \mathrm{ppm}$ & $4.34 \mathrm{~b}$ & $2.425 \mathrm{a}$ & $1.873 \mathrm{a}$ & $0.207 \mathrm{a}$ & $0.017 \mathrm{a}$ \\
$3000 \mathrm{ppm}$ & $3.72 \mathrm{c}$ & $2.11 \mathrm{~b}$ & $1.40 \mathrm{c}$ & $0.21 \mathrm{~b}$ & $0.020 \mathrm{ab}$ \\
LSD 0.05 & 0.509 & 0.355 & 0.371 & 0.025 & 0.003 \\
\hline & Mustard & \multicolumn{4}{|c|}{6 day old } \\
\hline Control (Tap water) & $2.93 \mathrm{c}$ & $2.08 \mathrm{c}$ & $0.82 \mathrm{c}$ & $0.17 \mathrm{c}$ & $0.039 \mathrm{a}$ \\
$1000 \mathrm{ppm}$ & $3.32 \mathrm{~b}$ & $2.29 \mathrm{~b}$ & $0.96 \mathrm{~b}$ & $0.22 \mathrm{ab}$ & $0.041 \mathrm{~b}$ \\
$2000 \mathrm{ppm}$ & $3.52 \mathrm{a}$ & $2.58 \mathrm{a}$ & $1.10 \mathrm{a}$ & $0.24 \mathrm{a}$ & $0.048 \mathrm{~b}$ \\
$3000 \mathrm{ppm}$ & $3.34 \mathrm{~b}$ & $2.42 \mathrm{ab}$ & $0.98 \mathrm{~b}$ & $0.21 \mathrm{~b}$ & $0.040 \mathrm{~b}$ \\
LSD 0.05 & 0.173 & 0.189 & 0.098 & 0.018 & 0.0684 \\
\hline
\end{tabular}

Means in each column for followed by the same letter are not significantly different at the $5 \%$ level 
Canola and mustard dry weight decreased as $\mathrm{NaCl}$ concentration increased. The dry control mustard sprout recorded the highest percentage loss in sprout dry matter (about 25\%) compared with loss in control canola sprout dry matter (about 4.3) (Table 1). The more percentage loss in control mustard sprout than in canola sprout may be due to the hydroponic sprout production for 6 day for mustard sprouts comparsed to 3 day sprouting for canola sprouts which may loss less during respiration period. The decreased dry weights during sprouting results are in agreement with those reported by Chavan and Kadam (1989), Wanasudara et al (1999) and Anwar et al (2015)

\section{2- Effect of canola and mustard sprouts on ex- perimental rats.}

\section{A- Effect of semi-modified diets on blood glu- cose}

Concerning blood glucose levels measured at the end of the experiment (6 weeks after feed treatment), data in Table (2) showed hyperglycemia with STZ diabetic control and treated groups by mustard sprout (groups 5 and 6 ). The hyperglycemia with STZ diabetic control was observed during the whole 6 weeks (studied period) with blood glucose increment which amounted $283.4 \mathrm{mg} / \mathrm{dl}$ at last week of the experimental period. The significant increases in blood glucose level in STZdiabetic are in agreement with Bukan et al (2003), Amer et al (2004), Akbarzadeh et al (2007) and El-Abd et al (2007) and Aly Tahany et al (2015).

Feeding diabetic rats on canola or mustard semi-modified diets for 6 weeks studied period decreased the hyperglycemia but it was more than normal state compared with normal treatments. The decreased in blood glucose levels recorded about 122.5 and $128.7 \mathrm{mg} / \mathrm{dl}$ in STZ induced diabetic rats treated with the diets containing SWS canola (NaCl 1000 ppm) and TWS canola respectively. The diabetic control significantly showed about $283.39 \mathrm{mg} / \mathrm{dl}$ at the same time. On the other hand, mustard sprouts semi-modified diets decreased blood glucose levels to about 180.5 and $165.2 \mathrm{mg} / \mathrm{dl}$ in both SWS mustard ( $\mathrm{NaCl} 2000$ ppm) and TWS mustard, respectively with non significant with both negative or positive control.

In the present study, canola semi-modified diets significantly and gradually reduced blood glucose levels in STZ- diabetic rats during the 6 weeks of treatments which also demonstrated that there was a significant high rate of glucose disposal. Similar results were also obtained by Taniguchi et al (2006 and 2007) and Aly Tahany et al (2015) with Japanese and Egyptian radish sprouts and clover sprouts. However, the mechanism of these sprout which decreased blood glucose level, has not been clearly defined. Previous studies demonstrated that radish sprouts and radish extrct and their active constituent have proven free radical scavenging and antioxidant activates (Sgherri et al 2003, Peluso 2006, Wang et al 2010 and Zhou et al 2013).

The canola or mustard sprouting with tap water or saline water, semi-modified diets were effactive as hypoglycemic agents where glucose levels reduced at the end of experimental period by about $90 \%$.

Table 2. Effect of TWS and SWS of canola and mustard, semi-modified diets on fasting blood glucose and body weight, of experimental rats.

\begin{tabular}{|c|c|c|c|c|}
\hline \multirow{2}{*}{$\begin{array}{c}\text { Rat } \\
\text { Groups }\end{array}$} & \multicolumn{2}{|c|}{$\begin{array}{l}\text { Fasting blood } \\
\text { glucose (FBG) }\end{array}$} & \multicolumn{2}{|c|}{$\begin{array}{l}\text { Rats body weight } \\
\text { (g) }\end{array}$} \\
\hline & $\mathrm{Mg} / \mathrm{dl}$ & $\%$ & $G$ & $\%$ \\
\hline $\begin{array}{l}\text { G1-Normal } \\
\text { control }\end{array}$ & $119 b$ & 100 & $241.35 \mathrm{bc}$ & 100 \\
\hline $\begin{array}{c}\text { G2-Diabetic } \\
\text { control (+STZ }\end{array}$ & $283.39 \mathrm{a}$ & 238 & 220.72 c & 91.5 \\
\hline $\begin{array}{l}\text { G3- SWS } \\
\text { canola }\end{array}$ & $122.53 b$ & 103 & $284.27 \mathrm{ab}$ & 117.8 \\
\hline $\begin{array}{l}\text { G4- TWS } \\
\text { canola }\end{array}$ & $128.71 \mathrm{~b}$ & 108 & $304.01 \mathrm{a}$ & 126 \\
\hline $\begin{array}{l}\text { G5- SWS } \\
\text { mustard }\end{array}$ & $165.21 \mathrm{ab}$ & 139 & 240.29 bc & 99.6 \\
\hline $\begin{array}{l}\text { G6- TWS } \\
\text { mustard }\end{array}$ & $180.53 a b$ & 152 & $233.76 \mathrm{bc}$ & 96.9 \\
\hline LSD 0.05 & 126.55 & & 59.782 & \\
\hline
\end{tabular}

Means in each column followed by the same letter are not significantly different at the $5 \%$ level

B- Effect of SWS and TWS of canola and mustard semi-modified diets rats on rats body weight

Table (2) shows mean body weight of the experimental rats, 6 weeks after STZ injection at the end of the experiment (final weight). Data showed that STZ- induced diabetic rats fed on the normal diet had the lowest body weight. 
STZ- induced diabetic rats given diet containing $10 \%$ of canola sp had higher body weight than rats given normal diet either for diabetic control or normal control rats fed on normal diet at the end of experiment. Data was more pronounced with rats fed on diets containing $10 \%$ TWS canola. Previous studies showed that diabetic rats had significantly lower final-weight than control (AL-Rawi 2007a, Al-Logmanli and Zari 2009, Alnahdi, 2012 and Tahmasebpourl et al 2013 and Aly Tahany et al 2015).

The decrease in body weight of diabetic rats be due to catabolism of fats and protein. However, STZ- diabetic rats feeding on canola sprout especially TWS for 6 weeks showed increase in body weight which may be explained by increased insulin secretion; increased insulin- like compounds increased food consumption (Farouque and Meredith, 2003, Amer et al 2004 and Taniguchi et al 2007).

C- Effect of TWS and SWS of canola and mustard semi-modified diets on lipid profile of the experimental animals

Table (3) shows serum lipid profile (TC, TG, HDL-c, LDL-C and VLDL-c). Values were increased in STZ -induced diabetic control group when compared with normal control. The mustard sprout from both tap water (TWS) and saline water (SWS) semi- modified diets fed STZ- diabetic rats showed re- adjustment for TG, VLDL-c levels relative to control group. Percentage of recovery in the serum level of TG or VLDL-C was about $47.7 \%$ and 29.6 $\%$ by feeding on TWS and SWS mustard semimodified diets, respectively in respect to diabetic control. However, TWS canola semi-modified diets recover TG and VLDL-c by about $34.4 \%$ but LDL-c increased by about $143.8 \%$ in respect to diabetic control.

On the other hand, SWS canola semi-modified diets showed no significant effect on TG, VLDL-c and LDL-c. Moreover, HDL-c level showed no significant changes between groups (Table 3). However, the results of increasing levels of serum TG and VLDL-C in STZ-induced diabetic rats are in agreement with those abtained by Ravi et al (2005), Al-Logmanli and Zari (2009) and Alnahdi (2012).

The abonormal high concentration of serum lipid constituents in diabetic animals are due mainly to an increase in the mobilization of free fatty acids from the peripheral fat depots, since insulin inhibitis the hormone-sensitive lipase as reported by Pushparaj et al (2000). Diabetic rats converted fatty acids in serum into phospholipids and cholesterol in the liver. These two substances along with excess triglyceides formed at the same time in the liver may be discharged into the blood in the form of lipoproteins (Bopanna et al 1997). The present study showed that TWS, SWS mustard and TWS canola had favorably modified serum lipid profile in rats with decrease in triglyceride (TG) and VLDL-c.

Table 3. Effect of TWS and SWS of canola and mustaed semi-modified diets on lipid profile of the different experimental rats.

\begin{tabular}{|c|c|c|c|c|c|}
\hline Groups/Parameters & $\begin{array}{l}\text { Total choles- } \\
\text { terol }(\mathrm{mg} / \mathrm{dl})\end{array}$ & $\begin{array}{c}\text { Triglyceride } \\
(\mathrm{mg} / \mathrm{dl})\end{array}$ & $\begin{array}{l}\text { HDL-c } \\
(\mathrm{mg} / \mathrm{dl})\end{array}$ & $\begin{array}{l}\text { LDL-c } \\
\text { (mg/dl) }\end{array}$ & $\begin{array}{l}\text { VLDL-c } \\
\text { (mg/dl) }\end{array}$ \\
\hline G1.Normal control & $70.101^{c}$ & $59.32^{c}$ & $48.63^{a}$ & $20.04^{b}$ & $11.86^{c}$ \\
\hline $\begin{array}{c}\text { G2.Diabetic control } \\
(+\mathrm{STZ})\end{array}$ & $75.22^{c}$ & $154.09^{a}$ & $61.49^{a}$ & $19.46^{b}$ & $30.82^{a}$ \\
\hline G3. SWS canola & $90.36^{b}$ & $130.84^{a b}$ & $46.31^{a}$ & $21.01^{b}$ & $26.17^{\mathrm{ab}}$ \\
\hline G4.TWS canola & $110.24^{a}$ & $101.09^{a b c}$ & $42.57^{a}$ & $47.45^{\mathrm{a}}$ & $20.22^{a b c}$ \\
\hline G5.SWS mustard & $95.24^{b}$ & $80.52^{b c}$ & $57.81^{a}$ & $29.31^{b}$ & $16.11^{b c}$ \\
\hline G6.SWS mustard & $98.02^{a b}$ & $108.55^{a b c}$ & $60.15^{a}$ & $23.18^{b}$ & $21.71^{a b c}$ \\
\hline LSD 0.05 & 14.547 & 60.184 & N.S & 11.3 & 12.038 \\
\hline
\end{tabular}

N.S= Not significant.

Values in the same column with the same letter are not significant at $\mathrm{P} \leq 0.05$. 


\section{REFFERENCE}

Abdallah, M.M.F. 2008. Seed sprouts, a Pharaoh's heritage to improve food quality. Arab Univ. J. Agric. Sci., 16(2), 469-478.

Ahmed, F.A., Abdel-Lattife, M.S., Abd-El Azeem, A.S., Hegazy, A. M., Hassouna, H., Z. and Algalaly, M.A. 2014. The role of chitosan and wheat germ as antidiabetic substances in diabetic rats. res. J. Pharma. Biolog. Chem. Sci., 5(3), 457-469.

Akbarzadeh, A., Norouzian, D., Mehrabi, M.R., Jamshidi, S.H., Farhangi, A., Verdi, A., Mofidian S.M.A and Rad, B.L. 2007. Induction of diabetes by streptozotcin in rats. Ind. J. Clin. Biochem., 22(2), 60-64.

Al-Logmanli, A.Sh. and Zari, T.A. 2009. Effects of Nigella sativa L. and Cinnamomum zeylanicum Blume oils on some physiological parameters in streptozotocin-induced diabetic rats. Bol. Latinoam Caribe Plant Med Aromat, 8(2), 86 - 96.

Allain, C.C., L.S. Poon, C.S.G. Chan, W. Richmond and P.C. Fu, 1974. Enzymatic determination of total serum cholesterol. Clin. Chem., 20 (4), 470-475.

Alnahdi, H.S. 2012. Effect of Rosmarinus officinalis extract on some cardiac enzymes of streptozotocin-induced diabetic rats. J. Health Sci., 2(4), 33-37.

AL-Rawi M.M. 2007. Effect of Trifolium sp. flowers extracts on the status of liver histology of streptozotocin induced diabetic rats. Saudi J. Bio. Sci., 14, 21-28.

Aly, Tahany, A.A., Fayed S.A., Amal M. Ahmed and El-Rahim E.A. 2015. Effect of Egyptian radish and clover sprouts on blood sugar and lipid metabolisms in diabetic rats. Global J. Biotech. Biochem., 10(1), 16-21.

Amer, M.; El-Habibi, E.S. and El-Gendy, A. 2004. Effects of Trifolium alexandrinum extracts on streptozotocin-induced diabetes in male rats. Ann. Nutr. Met., 48(5), 343-347.

Anwar, D.A., Abou El-Yazied, A., Mohammadi, T. and Abdallah, M.M.F. 2015. Wheat grass juice and its nutritional value as affected by sprouting condition. Arab Univ. J. Agric. Sci., 23(1), 37-49.

Bahadoran, Z., M. Tohidi, P. Nazeri, M. Mehran, Azizi F. and Mirmiran P., 2012. Effect of broccoli sprouts on insulin resistance in type 2 diabetic patient: a randomized double-blind clinical trial. Int. J. Food Sci. Nutr., 26 p.

Bessesen, D.H., 2001. The role of carbohydrates in insulin resistance. J. Nutr., 131, 2782-2786.

Bopanna, K., Kannan, J., Sushma, G., Balaram, R. and Rathod, S. 1997. Antidiabetic and antihyperlipaemic effects of neem seed kernel powder on alloxan diabetic rabbits. Indian $\mathbf{J}$. Pharmacol, 29, 162 - 167.

Bukan, N., Sancak, B., Yavuz, O., Koca, C., Tutkun, F., Ozcelikay, A. T., and Altan, N. 2003. Lipid peroxidation and scavenging enzyme levels in the liver of streptozotocininduced diabetic rats. Indian J. Bioch. BioPhys., 40(6), 447-450.

Burstein, M., H.R. Scholnick and R. Morfin, 1980. Rapid method for the isolation of lipoproteins from human serum by precipitation with polyanions. Scand J. Clin. Lab. Invest., 40, 583-595.

Chavan, J. and Kadam, S.S. 1989. Nutritional improvement of cereals by sprouting. Critical Rev. Food Sci. Nutr., 28, 401-437.

Dzowela, B.H., Hove L. and Mafongoya, P.L. 1995. Effect of drying method on chemical composition and in vitro digestibility of multipurpose tree and shrub fodders. Tropical Grasslands., 29, 263-269.

El-Abd, M.M., Hassan, M.N.A., El-Baroty, G.E. and Abdel-Mobdy, A.E. 2007. Evaluation of CLA isomers as antiglycemic agents in albino rats. Egypt. J. Nutr., 22(4), 261-288.

Farouque, H. and Meredith L. 2003. Effects of inhibition of ATP sensitive potassium channels on metabolic vasodilation in the human forearm. Clin. Sci., 104, 39-46.

Faure, P., E. Rossini, J.L. Lafond, M.J. Richard, Favier A. and Halimi S., 1997. Vitamin E improves the free radical defense system potential and insulin sensitivity of rats fed high fructose diets. J. Nutr., 127, 103-107.

Fossati, P. and Prencipe L., 1982. Serum triglycerides determined calorimetrically with an enzyme that produces hydrogen peroxide. Clin. Chem., 28(10), 2077-2080.

Gajdosik, A., Gajdosikova, A., Stefek, M., Navarova, J. and Hozova, R. 1999. Streptozotocininduced experimental diabetes in male Wistar rats. General Physiology and Biophysics, 18, 54-62.

George, B.O., Osioma, E. and Falodun, A. 2010. Effect of Atiko (Aframomum sceptrum) and Af- 
rican nutmeg (Monodora myristica) on reduced glutathione, uric acid levels and liver marker enzymes in streptozotocin-induced diabeticrats. Egyptian J. Biochem. Mol. Biol., 28(2), 6778.

Hashimoto, T., Ueda Y., Oi N., Sakakibara, H., Piao C., Ashida H., Goto M. and Kanazawa K., 2006. Effects of combined administration of quercetin, rutin and extract of white radish sprout rich in kaempferol glycosides on the metabolism in rats. Biosci. Biotechnol. Biochem., 70(1), $279-281$.

Lee, S.H., Lim S.W., Lee Y.M., Lee H.S. and Kim D.K..2012. Polysaccharide isolated from Triticum aestivum stimulates insulin release from pancreatic cells via the ATP-sensitive $\mathrm{K}_{+}$ channel. Int. J. Mol. Med., 29 (5), 913-919.

Mao, X., Zhang L., Xia Q., Sun Z., Zhao X., Cai H., X. Yang, Xia Z. and Tang Y., 2008. Vanadium-enriched chickpea sprout ameliorated hyperglycemia and impaired memory in streptozotocin-induced diabetes rats. Biometals, 21(5), 563-570.

Peluso, M.R. 2006. Flavonoids attenuate cardiovascular diseae, inhibit phosphodiesterase, and modulate lipid homeostasis in adipose tissue and liver. J. of Exp Biol. Med. (Maywood). 231(8), 1287- 1299.

Penas, E., Gomez R., Frias J. and Vidalvalverde, C. 2008. Application of high-pressure on alfalfa (Medigo sativa) and mung bean (Vigna radiat) seeds to enhance the microbiological safety of their sprouts, Food Control, 19, 698-705.

Pushparaj, P., Tan C.H. and Tan B.K.H. 2000. Effect of Averrhoa bilimbi leaf extract on blood glucose and lipids in streptozotocin-diabetic rats. J. Ethnopha. 72(1), 69-76.

Rani, S. and Kumar, D. 2014. A case study on soft computing techniques used for diabetes mellitus. Int. J. Adv. Res. Computer Sci. Software Engineer. 4(7), 1-4.

Ravi, K., Rajasekaran, S. and Subramanian, S. 2005. Antihyperlipidemic effect of Eugenia jambolana seed kernel on streptozotocininduced diabetes in rats. Food Chem. Toxicol., 43, 1433-1439.

Sawyer, C.A., DeVitto A.K. and Zabik M.E. 1985. Food service systems: comparison of production methods and storage times for alfalfa sprouts. J. Food Sci. 50(1), 188-191.

Sgherri, C., Cosi E. and Navari-Izzo, F., 2003. Phenols and antioxidative staus of Raphanus sativus grown in copper exess. Physiol. Plant. 118(1), 21- 28.

Shermer, S., 1967. The Blood Morphology of laboratory Animals $3^{\text {rd }}$ Ed., Davis F.A. Co., Phila delphia, 42 p.

Snedecor, G.W. and Cochran W.G.. 1980. Statistical Methods. $7^{\text {th }}$ Ed. lowa State Univerity Press. Ames, lowa, USA. 507 p.

Tahmasebpourl, N., Dehghan, M., Feizil, A.H. and Esmaeili, H.A. 2013. Variation in body weight and somehematological parameters instreptozotocin-induced diabetic rats, treated with Teucrium orientale; http:// pharmacologyonline Archives (3), 32 - 36.

Taniguchi, H., Hattori K., Tenmyo K., Kamei C., Uda, T., Konishi Y.S., Oishi Y. and Takita, T. 2006. Effect of Japanese radish (Raphanus sativus) sprout (Kaiware-daikon) on carbohydrate and lipid metabolisms in normal and streptozotocin-induced diabetic rats. Phytother Res., 20 (4), 274-278.

Taniguchi, H., Muroi, R., Kobayashi-Hattori, K., Uda, Y., Oishi, Y. and Takita, T. 2007. Differing effects of water-soluble and fat-soluble extracts from Japanese radish (Raphanus sativus) sprouts on carbohydrate and lipid metabolism in normal and streptozotocin-induced diabetic rats. J. Nutrition Sci. Vitaminol. 53(3), 261-266.

Trinder, P. 1969. Determination of blood glucose using an oxidation peroxidase system with a non carcinogenic chromogene. Ann. Clin. Biochem., 6, 24-31.

Wanasundara, P.K.J.P.D., Shahidi, F. and Brosnan, M.E. 1999. Changes in flax (Linum usitatissmum) seed nitrogenous compounds during germination. Food Chem., 65(3), 289295.

Wang, L.S., Sun, X.D., Cao, Y., Wang L., Li F.J., and Wang, Y.F. 2010. Antioxidant and prooxidant properties of acylated pelargonidin derivatives extracted from red radish (Raphanus sativus var. niger, Brassicaceae). Food Chem. Toxicol., 48(10), 2712- 2718.

Wieland, H. and D. Seidel, 1983. A simple specific method for precipitation of low density lipoproteins. J. Lipid. Res., 24, 904- 909.

Wu, L.Y., C.C Juan, Ho L.T., Hsu Y.P. and Hwang L.S., 2004. Effect of green tea supplementation on insulin sensitivity in SpragueDawley rats. J. Agric. Food Chem., 52, 643648.

Yao H.T., Huang S.Y. and Chiang M.T., 2008. A comparative study on hypoglycemic and hypo- 
cholesterolemic effects of high and low molecular weight chitosan in streptozotocin-induced diabetic rats. Food Chem. Toxicol., 46(5), 1525-1534.
Zhou, C.; Zhu, Y., and Luo, Y. 2013. Effects of Sulfur Fertilization on the Accumulation of Health-Promoting Phytochemicals in Radish Sprouts. J. Agric. Food Chem., 61(31), 75527559. 
المؤتمر الرابع عثر لبحوث التمية الزراعية،

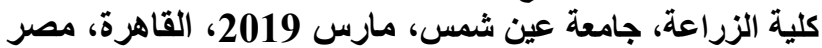

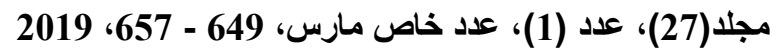

Website: http://strategy-plan.asu.edu.eg/AUJASCl/

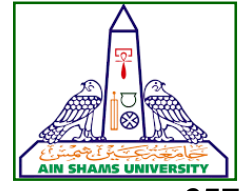

657

تأثير نبت بذور الكانولا والخردل على التمثيل الغذائي للاهون في الجرذان المصابه بداء السكري

هناء محمود عامر 1- تهاني عبدالغفار أحمد علي²- كريم مصطفى التويجي '- ممدوح محمد فوزي عبدالله -

\section{4}

1- معهد بحوث البساتين- مركز البحوث الزراعيه- الجيزة- مصر الجرات

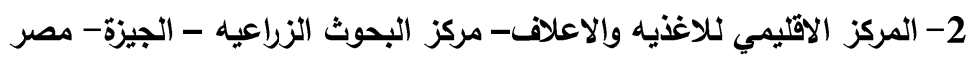

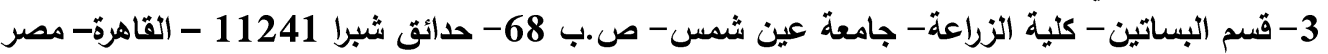

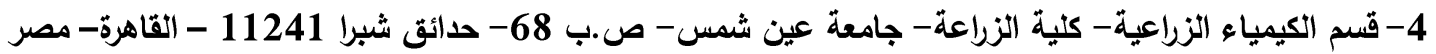

"Corresponding author: nonaamer637@gmail.com

Received 13 October, 2018,

Accepted 30 October, 2018

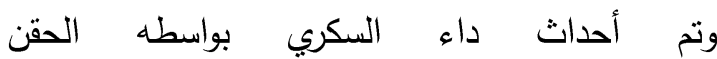
بالاستربتوزوتوسين (60 مج/ كجم من وزن الفأر ) .

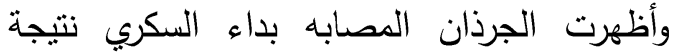

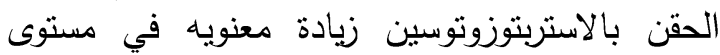

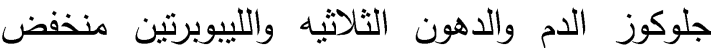
الكثافه (LDL-c) والمنخفض الكثافه جدا (VLDL-c) وأضافه نبت الكانولا والخردل الناتج بأستخدام ماء ألخاء

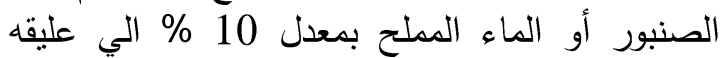

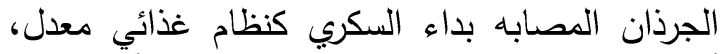
أدت لانخفاض جلوكوز الدم، وان الزيادة أو النقص

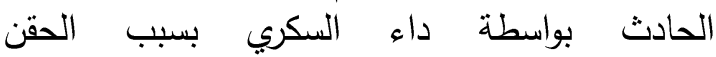
بالاستربتوزوتوسين قد تم تحسنها بواسطه النظام الغذائي المعدل بنبت الكانولا والخردل، ومن تلنين هذه النتائج

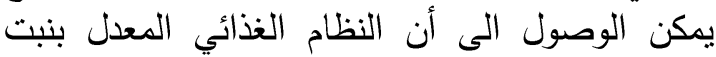

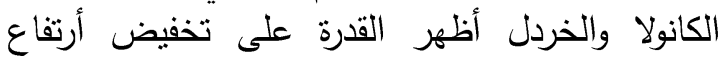

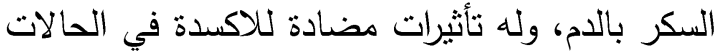

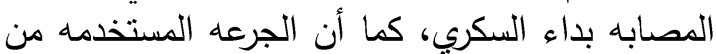

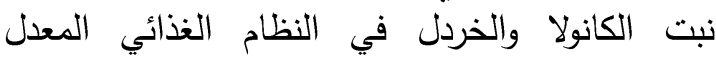

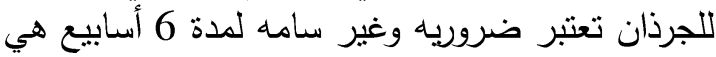

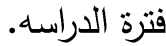

الكلمات الدالة: التمثيل الغذائي، الكانولا، المستردة،

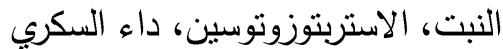<smiles>[Mg][TeH]</smiles>

تم اسخدام بذور الكانولا والخردل في انتاج النبت بعمر 3 أيام للكانولا و6 أيام للخردل باستخدام مياه

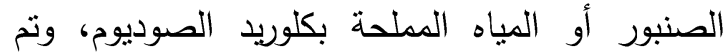

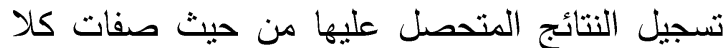
النوعين، واستخدم نبت بذور الكانولانيا والخردل لدراسه تأثيرهما علي خصائص السكر في دم الجرذان المصابة

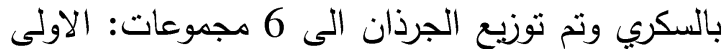

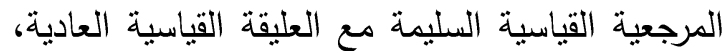

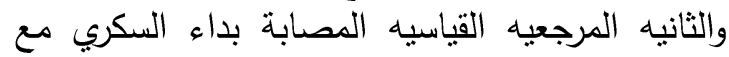

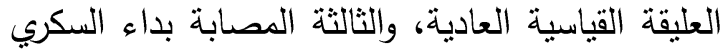

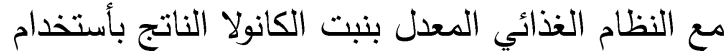

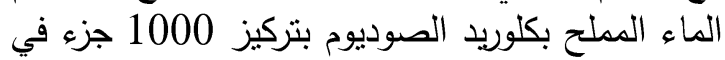
المليون، والرابعه المصابه بداء السكري مع نفس النظام

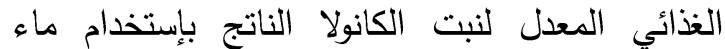

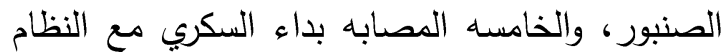
الغذائي المعدل بنبت الخردل الناتج بإستخدام الماء الثباء الملح بكلوريد الصوديوم بتركيز 2000 جزء في لئي

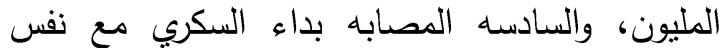
النظام الغذائي المعدل لنبت الخردل الناتج لئه بإستخدام

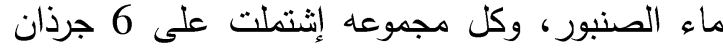

تحكيم: ا.د صبري موسى سليمان

ا.د فؤاد عبدالرحـــيم 